\title{
Evaluation of Women Farmers' Perception of the Impact of Women-in-Agriculture Programme on Yield, Income and Decision-making Power in Southeastern Nigeria
}

\author{
Ajah, J. \\ Department of Agricultural Economics/Extension, \\ University of Abuja, Abuja \\ E-mail: juliusajah2@yahoo.com; Mobile: +2348053188880
}

\begin{abstract}
One of the reasons that necessitated the establishment of Women-inAgriculture (WIA) Programme in 1989 was the perception that women farmers were not having adequate access to extension services compared to their male counterparts. Feminists argued that the inadequate access to extension services resulted in women farmers having poor farm yields, income, and decision-making power on what to produce. With the institutionalization of WIA programme since 1989, the study was conducted to evaluate the impact of the programme on women farmers' yield, income and decision-making power. Multi-stage sampling technique was adopted for sample selection while semi-structured questionnaires were used for data collection. Data collected from 225 contact women farmers were analyzed using Analysis of Variance (ANOVA) and tested at 5\% level. Mean separation was equally done with Fisher Least Significant Difference (FLSD). Generally, the grand mean perceptional value (4.21) indicated that women farmers perceived positive changes in their farm yields, income and decision-making power because of the influence of WIA Programme. Analysis of Variance on pooled data indicated that women farmers perceived significant differences $(P<0.05)$ in the changes in yield, income and decision-making power. The result, as well, showed that women farmers in the different State's agricultural zones in Southeastern Nigeria perceived significant differences $(P<0.05)$ in the changes in yield, income and decision-making power. Mean separation results showed that women farmers perceived the impact more on yield with perceptual mean value of $4.38^{a}$. It also revealed that women farmers in Oji agricultural zone in Enugu State had the highest impact in the Southeastern Nigeria with mean perceptional value of $4.61^{a}$. Based on the results, the paper strongly recommended that the implementers of the programme should be highly motivated in order to guarantee the sustainability of the programme for agricultural development.
\end{abstract}

Key words: contact women farmers, income, yield, decision-making power, WIA, 


\section{INTRODUCTION}

Over the last couple of decades, considerable effort has been made throughout the world to provide women farmers with efficient, effective, and appropriate technology, training, and information. In Nigeria, part of the efforts made in improving the status of women farmers resulted in the institutionalization of a gender sensitization and communication intervention programme known as Women-in-Agriculture (WIA) programme in 1989 (FACU, 1995). It was institutionalized by the Federal Government of Nigeria because of the need to improve extension services to women farmers. In fact, some of the major objectives of Women-in-Agriculture (WIA) programme are to increase women farmers' yield (output) and income. Hence, in the guideline for the implementation of the programme, it was categorically stated thus: "sociological, agronomic and economic indices are used in measuring the impact of the programme, example, incremental yields and income of women farmers" (FACU, 1995). Improvement in decision-making power is equally implied in the above objectives because whenever farmers are asked to change their production pattern or habits, either by incorporating new information or excluding some traditionally used criteria, it is likely that resistance will occur and this will lead to changes in decision-making especially, when the change involves risk

The argument that necessitated the institutionalization of WIA programme in 1989 was that women farmers were marginalized in our society. This view was supported by Jayaweera, et al. (1994) when they stated that the gender role assumptions of middle class planners, both national and expatriate, and administrators have been based on the ideology of the domestication of women. According to them, women have been perceived as house wives or farm wives rather than farmers and this gender ideology, they said, is clearly reflected in policies that affect access to the means of production and the social relationships of production. In the same view, Heyzer (1994) stated that the needs of women from the poorest strata of rural society have long been ignored or overlooked in an attempt to raise rural productivity and to create access to land, employment, credit and new opportunities and skills for the poor.

In the same view, Bamberger (1994) stated that agricultural projects have also been designed on the assumption that the male "household" is the main agricultural workers and decision-maker; consequently, most technical assistance and productive inputs are directed towards the male members of the household leaving women as mere dependants rather than participants. Conway and Lambrow (1995) attributed this marginalization, of women, to serious lack of understanding of gender in our society and its implications for development. Because of this lack of understanding according to them, development efforts for a long time have been carried out on the assumption that development that benefits men will automatically benefits women. The implication of this according to Dunmade (1990) is that, women experience considerable difficulties in securing access to agricultural services such as extension, provision of agricultural inputs, credits, market facilities and technical assistance. 
In full support of the fact that women farmers are marginalized in our society, Chale (1991) stated that, in agricultural extension, most of the Village Extension Agents (VEA) were males. Based on this (according to her) male farmers had more contacts with the agricultural extension system than female farmers. She further stated that, the consequences of this male-biased extension system were two-dimensional: First, lack of contact with extension agents precludes women from having knowledge of improved agricultural practices. Secondly, women's onthe-spot agricultural production problems, are not relayed to the research centers hence technology for solving women's specific agricultural problems are not always available. Another issue, according to her, is that it is extremely difficult for women to have access to means of production, modern cultivation techniques, training programmes, decision-making bodies and these are factors which on the whole affect women.

Further evidence of women marginalization is seen in a regional study documented by Thrupp and Green (1995), which showed that women represented only $11 \%$ of the total extension staff in Africa. According to the report, women were not only under-represented as extensionists, but they also tend to be neglected by male extensionists at the farm level. Technologies for agricultural development according to the report were generally targeted towards male producers and infrequently serve women's needs. Reilly and Gordon (1995) stated that many of these problems and constraints women face are "a function of the social division of labour, their socially determined roles, and the resulting inequalities between men and women in responsibilities, opportunities, access to resources and rewards". It follows according to Reach (1995) that, women's effective and meaningful participation in development is greatly hampered by their subordinate positions at the household level. Since one of the approaches to end this perceived marginalization of women farmers was the institutionalization of WIA programme in 1989 , there is every need to evaluate this programme to determine if women are feeling the programme's impact or not.

\section{METHODOLOGY}

This study was carried out in Southeastern Nigeria made up of Abia, Enugu, Ebonyi, Imo and Anambra States. Multi-stage sampling technique was adopted for sample selection while semi-structured questionnaires were used for data collection. Out of the 5 States in the Southeastern Nigeria, 3 States - Abia, Enugu and Ebonyi, were randomly selected. In each of the 3 States sampled, 3 agricultural zones were selected. Next, 5 Agricultural Extension Blocks were randomly selected giving a total of 15 blocks. From each of the 5 Agricultural Extension Blocks, 5 circles were randomly selected giving a total of twenty five (25) Circles per State's agricultural zone. Finally, in each Agricultural Extension Circle, contact women farmers were randomly selected but only one properly filled questionnaire was used because the analysis needed equal observations per block. This gave a total of 25 respondents per State's agricultural zone and a total of seventy five (75) respondents for the 3 zones in each State. For the three (3) States, a sample size of $225(75 \times 3=225)$ respondents was used. 
For proper understanding and interpretation of the questions in the questionnaires, the researcher liaised with the staff of Agricultural Development Programme (ADP) in each of the selected States and they helped to recruit WIA frontline staff that assisted in data collection. The frontline staff were trained and mobilized as enumerators for the data collection while the researcher supervised the exercise. The WIA frontline staff used interview method during data collection. In the interview schedule, the women farmers were asked to express the changes that occurred in their yield, income and decision-making power due to the influence of WIA programme using a 5-point scale - significant increase (5), slight increase (4), no change (3), slight decrease (2) and significant decrease (1). The scores were subjected to Analysis of Variance (ANOVA) and tested at 5\% probability level. Mean separation was equally done using Fisher's Least Significant Difference (FLSD).

\section{Model Specification for Data Analysis}

The general model specification for data analysis is expressed mathematically as:

$Y_{i j}=\mu+T_{i}+\beta_{j}+e_{i j}$

Where:

$Y_{i j}==\quad$ individual observations, i.e. observation for the $i^{\text {th }}$ treatment in the $j^{\text {th }}$ block

$\mu \quad=$ general mean

$\mathrm{T}_{\mathrm{i}}=$ effect on the $\mathrm{i}^{\text {th }}$ treatment

$\beta_{j}=$ effect on the $j^{\text {th }}$ block

$e_{\mathrm{ij}}=$ random error variable

Treatment: Treatment here refers to yield, income and decision-making power.

Block: Block here refers to the existing States' Agricultural Extension Zones as partitioned or delineated by Agricultural Development Project (ADP) in the sampled States. They include Umuahia, Aba, Ohafia (Abia State); Ebonyi, Onueke, Afikpo (Ebonyi State); Enugu, Nsukka, Oji (Enugu State).

Replication: Replication here refers to the number of respondents per block.

\section{RESULTS AND DISCUSSION}

Results of the analysis are presented in tables 1-3 below.

Table 1 shows the ANOVA results for women farmers' perception of the impact of WIA Programme on their yield (output), income and decision-making power. In Abia State, the F-calculated (3.61) for the indicators was greater than F-tabulated (3.00) implying that women farmers perceived significant differences $(P<0.05)$ in the changes in their yield, income and decision-making power due to involvement in WIA Programme. Enugu State had the same result because F-calculated (3.43) for the indicators was greater than F-tabulated (3.00). The result was not the same 
in Ebonyi State where the F-calculated (0.61) was less than F-tabulated (3.00) implying that significant changes were not perceived by women farmers in Ebonyi State. The ANOVA results also revealed that in Abia and Ebonyi States, there were no zonal differences in women farmers' perception of the impact of WIA Programme on their yield, income and decision making power. The F-calculated for Abia (0.46) and Ebonyi (0.13) States were less than the F-tabulated (3.00) indicating that there was no significant difference $(P>0.05)$. In Enugu State, there was a zonal difference in women farmers' perception of the influence of WIA Programme on their yield, income and decision-making power. The F-calculated (12.29) was greater than the F-tabulated (3.00) indicating significant difference ( $P$ $<0.05)$.

At block level, pooled data (ANOVA results) showed that the F-calculated (5.70) was greater than the F-tabulated (1.94) implying that women farmers in the Southeastern Nigeria perceived significant differences $(P<0.05)$ in the changes in their yield, income and decision-making power due to the influence of WIA Programme. The result, as well, indicated that women farmers in the different State's agricultural zones, in the Southeastern Nigeria, perceived significant $(P<$ 0.05 ) differences in the changes in their yield, income and decision making power. This is reflected on the F-calculated (5.75) which was greater than F-tabulated (1.94).

TABLE 1: ANOVA for Women Farmers' Perception of the Influence of WIA Programme on their Yield, Income and Decision-making Power

Abia State

\begin{tabular}{lccccc}
\hline \multicolumn{1}{c}{ Source of variation } & Df & SS & MS & F-Cal & F-Tab (5\%) \\
Indicators & 2 & 3.53 & 1.77 & 3.61 & 3.00 \\
State's Agricultural Zones & 2 & 0.46 & 0.23 & 0.46 & 3.00 \\
Error & 220 & 109.14 & 0.49 & & \\
Total & $\mathbf{2 2 4}$ & $\mathbf{1 1 3 . 1 3}$ & & & \\
Ebonyi State & & & & & \\
$\quad$ Source of variation & Df & SS & MS & F-Cal & F-Tab (5\%) \\
Indicators & 2 & 1.56 & 0.78 & 0.61 & 3.00 \\
State's Agricultural Zones & 2 & 0.34 & 0.168 & 0.13 & 3.00 \\
Error & 220 & 280.09 & 1.27 & & \\
Total & $\mathbf{2 2 4}$ & $\mathbf{2 8 1 . 9 9}$ & & &
\end{tabular}




\section{Enugu State}

\begin{tabular}{llrlll}
$\quad$ Source of variation & \multicolumn{1}{c}{ Df } & SS & MS & F-Cal & F-Tab (5\%) \\
Indicators & 2 & 10.14 & 5.07 & 3.43 & 3.00 \\
State's Agricultural Zones & 2 & 36.38 & 18.19 & 12.29 & 3.00 \\
Error & 220 & 325.94 & 1.48 & & \\
Total & 224 & 372.46 & & & \\
Pooled data & & & & & \\
$\quad$ Source of variation & Df & SS & MS & F-Cal & F-Tab (5\%) \\
Indicators & 2 & 13.21 & 6.61 & 5.70 & 3.00 \\
State's Agricultural Zones & 8 & 49.71 & 6.21 & 5.75 & 1.94 \\
Error & 664 & 717.19 & 1.08 & & \\
Total & $\mathbf{6 7 4}$ & $\mathbf{7 8 0 . 1 1}$ & & & \\
\hline
\end{tabular}

Based on these results, mean separation was done (see table 2) to determine which indicator (yield, income or decision-making power), that significantly differed from each other and again, the State's agricultural zone that perceived the influence of WIA Programme more than the other. In Abia State, the women farmers perceived positive changes in their yield and decision-making power with mean perceptional values of $4.53^{\mathrm{a}}$ and $4.38^{\mathrm{a}}$ respectively. There was no significant difference in the mean perceptional values but the value for yield $\left(4.53^{\mathrm{a}}\right)$ was greater than that of decision-making power $\left(4.38^{\mathrm{a}}\right)$ implying that the women farmers perceived more changes in their yield more than in their decision-making power. The least was income with mean value of $4.22^{\mathrm{b}}$.

In Ebonyi State, the result was different. There was no significant difference between the mean perceptional values signifying that the women farmers perceived equally changes in their yield, income and decision-making power. Although, the mean perceptional values were not significantly different, the mean value for income $\left(4.28^{\mathrm{a}}\right)$ was the highest. Also in Enugu State, the mean perceptional values indicated that the women farmers felt changes in their yield and decision-making power $\left(4.05^{\mathrm{a}}\right)$ more than income $\left(3.78^{\mathrm{b}}\right)$. The mean perception values for yield and decision-making power were not significantly different from each other but the mean value for yield $\left(4.30^{\mathrm{a}}\right)$ was greater than that of decision-making power $\left(4.05^{\mathrm{a}}\right)$ signifying more positive impact. Pooled data results showed that women farmers in the Southeastern Nigeria perceived more positive changes in their yield due to the influence of WIA Programme. This is seconded by decision-making power and least on income with mean perceptional values as $4.38^{\mathrm{a}}, 4.23^{\mathrm{b}}$ and $4.04^{\mathrm{c}}$ respectively. 
Generally, the grand mean perceptional value (4.21) indicated that WIA programme made a positive impact on the yield, income and decision-making power of the women farmers. The value (4.21) tended towards "significant increase". Positive changes in the yield of the women farmers was expected because similar study conducted by Ajah et al. (2009) indicated that women farmers in the Southeastern Nigeria perceived positive changes in their access to improved crops/seedlings compared to other farm inputs. Although changes in the women farmers' income were perceived to be the least, it was not supposed to be so because increase in yield is expected to lead to increase in income. Nevertheless, it could be that the price of the farm outputs was low or that part of the outputs was consumed at the household level because according to Adeyemo (1990), women farmers grow food crops on a subsistence level, mainly for their family use and only the extra is sold out. He went further to state that even money so generated is ploughed back into the family welfare.

\section{TABLE 2: Mean Separation of Women Farmers' Perception of the Influence of WIA Programme on their Yield, Income and Decision-making Power}

\begin{tabular}{|c|c|c|c|c|}
\hline \multirow[b]{2}{*}{ Indicators } & \multicolumn{3}{|c|}{ Mean Perceptional value } & \multirow[b]{2}{*}{ Pooled date } \\
\hline & Abia & Ebonyi & Enugu & \\
\hline Output & $4.53^{\mathrm{a}}$ & $4.18^{\mathrm{a}}$ & $4.30^{a}$ & $4.38^{\mathrm{a}}$ \\
\hline Income & $4.22^{b}$ & $4.28^{\mathrm{a}}$ & $3.78^{\mathrm{b}}$ & $4.04^{c}$ \\
\hline Decision-making power & $4.38^{\mathrm{a}}$ & $4.22^{\mathrm{a}}$ & $4.05^{\mathrm{a}}$ & $4.23^{b}$ \\
\hline Grand mean & 4.37 & 4.23 & 4.04 & 4.21 \\
\hline
\end{tabular}

Note: Means with the same alphabet do not significantly differ from each other. Source: Field Data, 2006

At the zonal or block level (see table 3), Umuahia, Aba, and Ohafia Agricultural Extension Zones have mean perceptional values of $4.32^{\mathrm{a}}, 4.40^{\mathrm{a}}$ and $4.42^{\mathrm{a}}$ respectively. The implication of these values is that women farmers in each of these Agricultural Extension Zones felt the impact of WIA programme the same way the other zones did. That is, there was no significant difference in the women farmers' perception of the impact of WIA programme on their yield, income and decision-making power in each of the Agricultural Extension Zones. But within Enugu State, the mean separation results showed that women farmers in Oji Agricultural Extension Zone perceived positive changes in their yield, income and decision making power more than those in Enugu and Nsukka Agricultural Extension Zones. The Agricultural Extension Block mean perceptional values for 
Enugu and Nsukka zones were $3.82^{\mathrm{b}}$ and $3.70^{\mathrm{b}}$ respectively and they were not significantly different from each other while that of Oji is $4.61^{\mathrm{a}}$.

Mean separation on pooled data indicated that women farmers in Oji Agricultural Extension Zone in Enugu State, Ohafia and Aba Agricultural Extension Zones in Abia State, felt the impact of WIA Progamme more than those in other Agricultural Extension Zones in Southeastern Nigeria. The Agricultural Extension Block mean perceptional values were $4.61^{\mathrm{a}}, 4.42^{\mathrm{ab}}$ and $4.40 \mathrm{abc}$ respectively. Although, the block mean perceptional values were not significantly different from each other, the study indicated that the value for Oji Agriculture Extension Zone $\left(4.61^{\mathrm{a}}\right)$ was the highest signifying that women farmers in Oji (in Enugu State) had the highest positive impact of WIA Programme in the Southeastern Nigeria.

TABLE 3: Mean Separation of Women Farmers' Perception of the Influence of WIA on their Income, Yield and Decision-making Power at zonal level

\begin{tabular}{clcc}
\hline \multirow{2}{*}{ States } & \multicolumn{1}{c}{$\begin{array}{c}\text { States' Agric } \\
\text { Zones }\end{array}$} & Block means & Pooled data \\
\hline \multirow{4}{*}{ Abia } & Umuahia & $4.32^{\mathrm{a}}$ & $4.32^{\mathrm{bc}}$ \\
& Aba & $4.40^{\mathrm{a}}$ & $4.40^{\mathrm{abc}}$ \\
& Ohafia & $4.42^{\mathrm{a}}$ & $4.42^{\mathrm{ab}}$ \\
& & & \\
Ebonyi & Ebonyi & $4.18^{\mathrm{a}}$ & $4.18^{\mathrm{c}}$ \\
& Onueke & $4.28^{\mathrm{a}}$ & $4.28^{\mathrm{bc}}$ \\
& Afikpo & $4.22^{\mathrm{a}}$ & $4.22^{\mathrm{bc}}$ \\
& & & \\
Enugu & Enugu & $3.82^{\mathrm{b}}$ & $3.82^{\mathrm{d}}$ \\
& Nsukka & $3.70^{\mathrm{b}}$ & $3.70^{\mathrm{d}}$ \\
& Oji & $4.61^{\mathrm{a}}$ & $4.61^{\mathrm{a}}$ \\
\hline
\end{tabular}

Note: Means with the same alphabet do not significantly differ from each other. Source: Field data, 2006.

The zonal differences in women farmers perception of the influence of WIA Programme on their yield, income and decision-making power was expected because agricultural and family activities according to Johnson and Kellogg (1984) are generally influenced by physical, economic, and socio-cultural factors which tend to change with time, and are different among geographic areas within the 
country. They further went on to state that topography, climate and water availability in different zones where crops exhibit roughly, the same biological expression (agro-climatic zones) dictate options for the adaptation of relevant technology. This condition may have been responsible for the significant differences in the incremental changes in women farmers' yield, income and decision-making power at the zonal level.

\section{CONCLUSION AND RECOMMENDATIONS}

In 1989, the Federal Government of Nigeria institutionalized Women-in-Agriculture (WIA) Programme. One of the major goals of the programme was to influence the way women farmers and their farm families make decisions and improve their productivity. In view of the existence of this programme since 1989, this study was conducted to evaluate women farmers' perception of the impact of the programme on their yield, income and decision-making power in the South-eastern Nigeria. Results from data analysis indicated that: women farmers perceived positive changes in their yield, income and decision-making power due to the influence of the programme; incremental changes were perceived more on yield followed by decision-making power and then income; the perceived positive changes in yield was significantly greater than that of decision-making power while that of decisionmaking power was significantly greater than income; in the three states sampled Abia, Ebonyi and Enugu - some of the State's Agricultural Extension Zones significantly differed from others in terms of women farmers' perception of the influence of WIA Programme on their yield, income and decision-making power; Oji agricultural zone (i.e. women farmers in Oji) in Enugu State, perceived the influence of WIA Programme on their yield, income and decision-making power more than other zones. From the foregoing, it can be concluded that WIA Progarmme impacted positively in the lives of the rural women farmers in the Southeastern Nigeria.

Based on the results therefore, the paper strongly recommended that WIA Programme should be sustained and improved for the benefits of women farmers. More research into some of the factors that influence WIA should be investigated and addressed from time to time because extension evaluation conducted regularly during programme implementation will indicate the potential value of a programme. Again, the organizational structures of Federal Ministry of Agriculture and Water Resources (FMAWR), departments, parastatals and agencies should be reorganized to house or reflect linkage points of the WIA Programme in Nigeria. 


\section{REFERENCES}

Adeyemo, O. A. (1990) Women in Development: An National Center for Economic Management and Administration (NCEMA) Workshop Report Co-sponsored by the Ford and Rockefeller Foundations, Feb. 1990, Ibadan, Pp.1-9.

Ajah, J.; Unamma, R. A. P. and I. Nwachukwu, (2009) Perceptional Evaluation of the Influence of Women-in-Agriculture Programme on Women Farmers' Access to Farm Inputs in Southeastern Nigeria. Proceedings of the International Conference on Sustainable Development, Vol 4, No. 4. Pp. 4044.

Bamberger, M. (1994) Gender and Poverty in Socialist Economics: The World Bank Experience in Gender. P 337.

Chale, F. U. (1991) How to Reach and Work with Rural Women: A Paper Presented at the Specialized Workshop on Extension Strategies for Reaching Rural Women held on $4^{\text {th }}-8^{\text {th }}$ February 1991at Yankaba, Kano State, Pp. 2 -10.

Conway, E. and Y. Lambrow (1995) Gender and Development: Equity for all. The International Development Research Centre: Gender Equity, Social Development Summit, Vol. 23, No. 2 July 1995, pp.4-7.

Dunmade, V. B. (1990) Transferable New Technologies Identified in Food Processing, Storage and Utilization. Proceedings of the NSAD/FAO/UNDP Specialized Course on Extension Delivery to Rural Women by Women in Development held at Niger State ADP Zonal Headquarters, Bida, July $30^{\text {th }}$ - August 1990, Pp. 115-116.

FACU (1995) Federal Agriculture Coordinating Unit: Guidelines for Women in Agriculture in Nigeria. FACU Publications Vol. 2, No. 2, Field Manual. Pp. 120.

Heyzer, N. (1994) Increasing Women's Access to Credit in Asia: Achievements and Limitations. In: Heyzer, N. and Sen, G (eds). Gender, Economic Growth and Poverty Market Growth and State Planing in Asia and the Pacific. Crescent Printing Works PVT Ltd, New Delhi. P. 284.

Jayaweera, S.; M. D. Dias and W.N. Goonewardene (1994) Women and Poverty: The Experience of the Accelerated Mahaweli Development Programme in Seri Lanka. In: Heyzer, N. and G. Sen (eds). Gender, Economic Growth and Poverty. Market Growth and State Planning in Asia and the Pacific. Crescent Printing Works PVT Ltd, New Delhi. P. 218.

Johnson, S. H. and Kellogg, E. D. (1984). Extension Role in Adapting and Evaluating New Technology Farmers. In: Swanson B. E. (ed.), Agricultural Extension: A Reference Manual ( $2^{\text {nd }}$ edition), FAO, Rome, Pp. 40-56.

Reach, P. (1995) Gender and Sustainable Devdelopment in Katheka, Kenya. In: Sigot, A. J.; Thrup, L. A. and J. Green (eds.). Towards Common Ground. Gender and Natural Resources Management in Africa. African Centre for Technology Studies, Nairobi, Kenya, p. 100. 
Reilly, C. O. and A. Gordon (1995) Survival Strategies of Poor Women in Urban Africa: The Case of Zambia NRI Socio-economic Series 10, Chatham, UK: Natural Resources institutes. Pp. 1-3.

Thrupp, L. A. and J. Green (1995) Reflection on Gender in National Resources Management. In: Sigot, A.; Thrupp, L. A. and J Green (eds.). Gender and Natural Resources Management in Africa. African Centre for Technology Studies (ACTS), Nairobi, Kenya, Pp. 111-114. 